\title{
NUOTOLINIŲ ERGOTERAPIJOS UŽSIĖMIMŲ POVEIKIS SERGANČIŲJŲ IŠSĖTINE SKLEROZE GYVENIMO KOKYBEI IR SAVARANKIŠKUMUI
}

\author{
Erika Liubinaitė, Evelina Lamsodienè \\ Kauno kolegijos Medicinos fakultetas
}

Raktažodžiai: išsėtinè sklerozè (IS), nuotolinè ergoterapija, gyvenimo kokybė, kasdiené veikla (ADL), savarankiškumas, ergoterapija.

\section{Santrauka}

Šiuo metu išsètine skleroze serga daugiau nei $2,5 \mathrm{mi}-$ lijono žmonių. Prasidejjus COVID-19 pandemijai, viso pasaulio šalys pradejo riboti kontaktus, todèl sergantiesiems išsètine skleroze buvo sunkiau gauti gydymo paslaugas. Tyrimo tikslas - ivvertinti nuotolių ergoterapijos užsièmimų poveikị sergančiųjų išsètine skleroze gyvenimo kokybei ir savarankiškumui. Įvertinus sergančiųjų išsètine skleroze gyvenimo kokybę, nustatyta, kad tiriamujų grupejje gyvenimo kokybès lygis yra vidutinis. Vertinant sergančiujų kasdienę veiklą nustatyta, kad jiems reikalinga pagalba judeti lauke ir patalpoje, persikelti, maudytis vonioje (duše), rengtis, maitintis, atlikti namų ruošos darbus. Mažiausiai, pagal kasdienės veiklos vertinimo klausimyną, tiriamiesiems pagalbos reikia tokiose veiklose, kaip valgio gaminimas, sfinkteriu kontrole, asmeninis tualetas ir bendravimas. Po taikytų nuotoliniu ergoterapijos užsièmimų sergančiujų išsėtine skleroze gyvenimo kokybė nepasikeitè, tačiau pagerèjo emocinè savijauta ir fizinè būklè. Nuotoliniai ergoterapijos užsièmimai pagerino sergančiųjų bendrą savarankiškumą ir atskiras jo veiklas, tokias kaip namų ruoša, vonia (dušas), valgio gaminimas, asmeninis tualetas, rengimasis ir maitinimasis. Tiriamųų nuotolinių užsièmimų patirtis ivertinta teigiamai.

\section{Ivadas}

Išsėtinè sklerozė (IS) yra viena iš labiausiai paplitusių centrinès nervų sistemos (CNS) ligų. Šiandien daugiau nei 2,8 milijono žmonių visame pasaulyje serga IS [10]. Labiausiai liga paveikia asmenu judejjimą, o tai sukelia didelių problemų emocinei gerovei, kasdienei veiklai (ADL) bei gyvenimo kokybei [7].
Žmonèms, sergantiems IS, reikalinga sudètinga priežiūra dèl neiggalumo, reikalaujančio visapusiško ligos valdymo. Medicininè reabilitacija yra priemonių visuma, padedanti asmenims, patyrusiems (arba galintiems patirti) negalią, pasiekti ir palaikyti optimalų fizinį, jutiminį, intelektinį, psichologinị ir socialinį funkcionavimą sąveikoje su aplinka [13]. Reabilitacijos tikslas yra pagerinti funkcinę nepriklausomybę ir sustiprinti socialinį dalyvavimą, ypatingą dèmesi skiriant pacientų švietimui ir savęs valdymui. Tikslui pasiekti naudojama programa, kurią vykdo sveikatos specialistų komandos: medicinos, slaugos, kineziterapijos, ergoterapijos, kalbos terapijos, socialinio darbo specialistai [1].

Ergoterapijos užsièmimai gali padèti pasiekti maksimalaus savarankiškumo kasdienejje veikloje. Pasak K. Maitra ir kt. [8], ergoterapija daro teigiamą poveikị šių asmenų savarankiškumui. Pagrindinis ergoterapijos tikslas yra suteikti pacientams galimybę savarankiškai dalyvauti kasdienejje, darbineje ir laisvalaikio veikloje, kurią jie nori ar turi atlikti. Sergantieji IS mokomi energijos taupymo principų, igyvendinant ịvairias strategijas, tokias kaip lengviau atliekamo darbo metodai arba ergonominès ịrangos naudojimas. Taikant ergoterapiją, atliekami pratimai gerinti koordinaciją, smulkiają motoriką, protinį budrumą ir pusiausvyrą. Taikomi korekcinai metodai, - pratimai, gerinantys pirštų miklumą, kad asmuo būtų savarankiškas. Ergoterapeutas padeda tobulinti įgūdžius, pritaikydamas darbinę ir namų aplinką, prietaisus, kurie sergantiesiems IS padètų atlikti ịprastinę kasdienę veiklą ir išmokytų energijos taupymo principų [5]. Iprastai IS gydymas vyksta reabilitacijos centruose ar ligoninése, todėl sergantieji turi vykti ị gydymo ịstaigas. Tai dažnai siejama su laiko ir finansinemis išlaidomis. Alternatyvus reabilitacijos metodas, naudojant technologijas ir vykdant nuotolinius užsiẻmimus, leidžia šias paslaugas teikti tiesiai i namus [2]. S. Keesara ir kt. [6] teigimu, tokio tipo gydymas egzistuoja dešimtmečius, tačiau labai plačiai nebuvo naudojamas, kol 2019 metais prasidejjo COVID-19 pandemija. Nesant galimybės vykdyti kontaktinių užsièmimų, teko rasti 
išeitị, kaip išspręsti šią kliūtį. Galima teigti, kad nuotolinis būdas yra viena iš išeičių atlikti ergoterapijos užsièmimus. Vieno iš atliktų tyrimų rezultatai parodè, kad nuotoliniu būdu atlikta reabilitacija yra naudinga ir perspektyvi platforma igyvendinti reabilitacijos paslaugas [4].

Tyrimo tikslas - įvertinti nuotolių ergoterapijos užsièmimų poveikị sergančiųjų išsètine skleroze gyvenimo kokybei ir savarankiškumui.

\section{Tyrimo medžiaga ir metodai}

Tyrimas buvo atliktas 2021 sausio- kovo mènesiais. Sergantiesiems IS buvo taikomi nuotoliniai 30-45 min. trukmès ergoterapijos užsièmimai. Užsièmimai organizuoti naudojant Zoom vaizdo programinę ịrangą. Iš viso dalyvavo $11(\mathrm{n}=11)$ tiriamųu, sergančių išsètine skleroze. Visiems tiriamiesiems buvo teikiami nuotoliniai ergoterapijos užsiè-

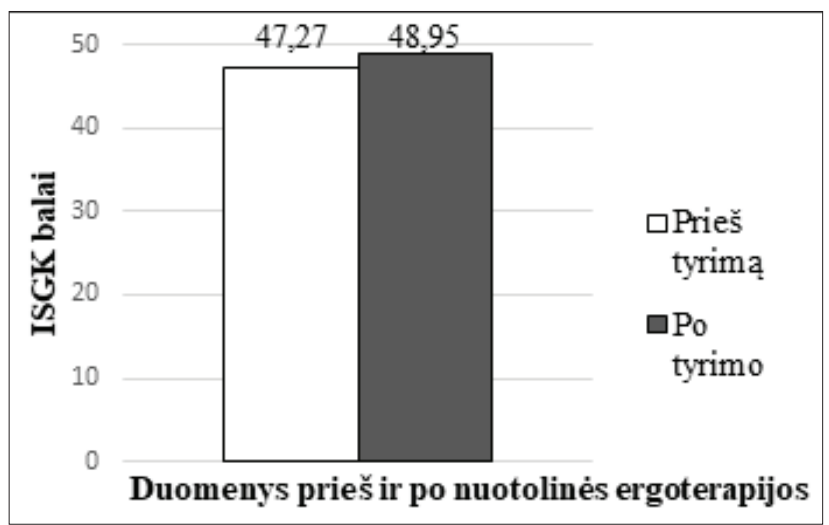

1 pav. Tiriamųjų gyvenimo kokybės pokytis (Sergančiųjų išsètine skleroze gyvenimo kokybès įvertinimo anketa)

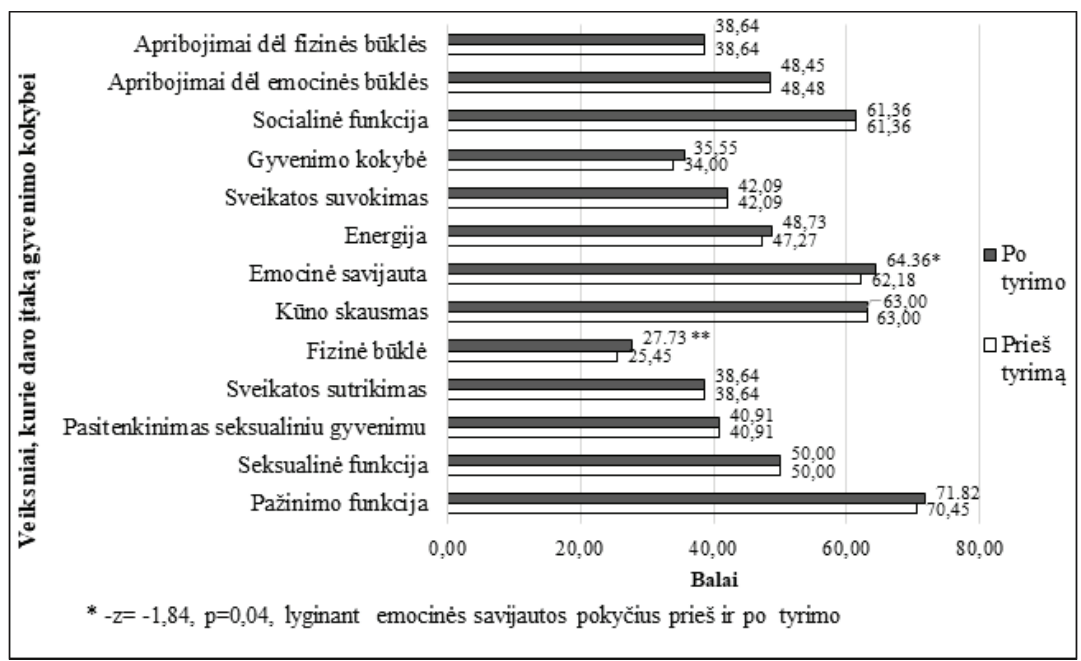

2 pav. Tiriamųjų pasiskirstymas pagal veiksnius, turinčius ịtakos gyvenimo kokybei

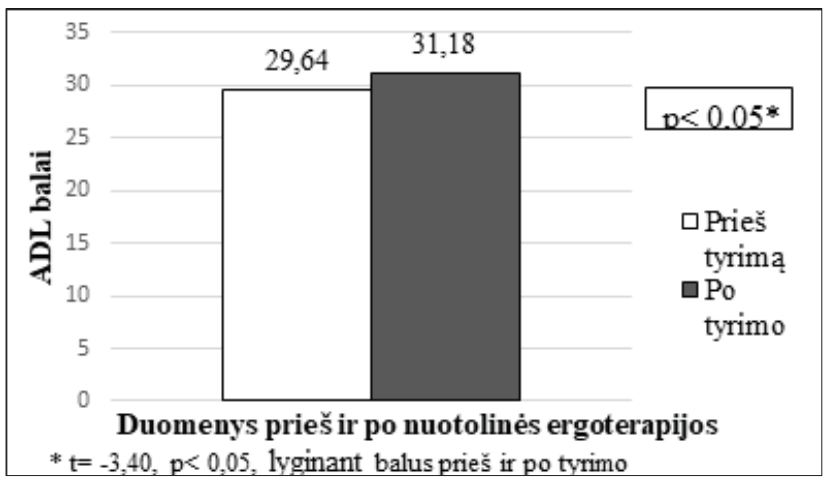

3 pav. Tiriamujų savarankiškumo pokytis (Kasdienės veiklos vertinimo klausimynas)

mimai. Jų metu buvo stiprinami rankos raumenys, gerinama judesių koordinacija, vikrumas, didinama sąnarių judesių amplitudè, gerinami turimi ịgūdžiai ir teikiama informacija, kaip savarankiškai lavinti prarastus ịgūdžius. Sergantys IS iš viso dalyvavo 15 užsiemimų, 2 kartus per savaitę. Tyrimo tikslui pasiekti buvo naudota apklausa, testavimas, statistinè duomenų analizè. Testavimas atliktas per pirmą ir paskutinị nuotolinį užsiėmimus. Vertinimo priemonès: anketa, sudaryta tyrèjo demografiniams duomenims rinkti; Kasdienès veiklos vertinimo klausimynas (ADL) [3]; Sergančiụjų išsėtine skleroze gyvenimo kokybès ịvertinimo anketa (ISGK) [12]; Telesveikatos pasitenkinimo apklausa [11]. Telesveikatos pasitenkinimo klausimynai naudojami vertinant nuotolinès sveikatos sistemos tinkamumą, vartotojų patirtị ir pasitenkinimą įvairiais technologijos aspektais [9].

\section{Tyrimo rezultatai}

Analizuojant sergančiujų išsètine skleroze gyvenimo kokybę tyrimo pradžioje ir pabaigoje, pakartotinio vertinimo metu pagerejjimo nebuvo nustatyta $(\mathrm{p}>0,05)(1$ pav.).

Atlikus pradini gyvenimo kokybės ịvertinimą, išskirta keturiolika gyvenimo kokybès sričių. Kiekvienos srities bendras rezultatas buvo lyginamas grupejje tarp tiriamujų pateiktų duomenų. Nors tiriamujų gyvenimo kokybė nepagerèjo, tačiau po 15 nuotolinių ergoterapijos užsièmimų buvo nustatyta, kad statistiškai reikšmingas $(\mathrm{p}<0,05)$ pagerèjimas pastebètas atskirose gyvenimo kokybés srityse, t.y. emocinè savijauta ir fizinè būklè (2 pav.).

Ivertinus kasdienès veiklos vertinimo 
klausimyno duomenis nustatyta, kad grupėje tiriamųų savarankiškumo suminis balas tyrimo pradžioje nesiskyrè $(\mathrm{p}>0,05)$. Daugiausia tiriamujų, atsakydami ị kasdienès veiklos vertinimo klausimyną, nurodé, kad nèra savarankiški ir jiems reikalinga pagalba tokiose veiklose, kaip judejimas lauke ir patalpoje, persikèlimas, vonia (dušas), rengimasis, namų ruoša, maitinimasis. Tyrimo pabaigoje pakartojus kasdienès veiklos klausimyną, pastebètas grupès tiriamųjų bendro savarankiškumo pagerèjimas $(\mathrm{p}<0,05)$ ( 3 pav.).

Tyrimo pradžioje buvo îvertinta, kad visiems tiriamiesiems daugiausia problemų kelia judejjimas patalpoje ir lauke. Savarankiškai judèti galèjo tik trečdalis grupès narių, kitiems tiriamiesiems reikalingos pagalbinès priemonès arba buvo visai nesavarankiški. Šios veiklos nepakito. Prieš nuotolinius ergoterapijos užsièmimus tik pusé tiriamujų galẻjo savarankiškai atlikti maitinimosi veiklą, po užsièmimų savarankiškų tiriamujjų skaičius trečdaliu padidejo $(\mathrm{p}<0,05)$. Net pusei tiriamujų iki tyrimo buvo reikalingos pagalbinès priemonès rengiantis, tačiau po nuotolinių užsièmimų ši veikla pagerèjo $(\mathrm{p}<0,05)$. Asmeninio tualeto atlikimo savarankiškumas padidejo $(\mathrm{p}<0,05)$. Didelè dalis tiriamųjų prieš tyrimą susidūrè su nesavarankiškumu namų ruošos veikloje, po tyrimo savarankiškumas šioje veikloje pagerejo $(\mathrm{p}<0,05)$. Savarankiškumas gaminant valgi po tyrimo taip pat pagerejjo $(\mathrm{p}<0,05)$, (4 pav.).

Apibendrinant gautus kasdienès veiklos vertinimo klausimyno rezultatus, matoma, jog nuotoliniai ergoterapijos užsièmimai pagerino tiriamųjų savarankiškumą.

Telesveikatos pasitenkinimo apklausos rezultatai rodo, kad po nuotolinių ergoterapijos užsièmimų tiriamieji teigiamai vertino garso bei vaizdo kokybę užsièmimo metu (1 lentelè), nuotoliniai užsièmimai tiriamiesiems buvo patogūs, puikiai jautèsi beveik visi tiriamieji. Taip pat tiriamieji vertino patekimą ị nuotolinius užsièmimus ir laiko trukmę, kuri buvo skirta užsiëmimams. Tiriamieji ịvertino ergoterapeuto kruopštumą, atsargumą ir sumanumą bei mandagumą, pagarbą, jautrumą ir draugiškumą, ši klausimą visi tiriamieji ịvertino vienodai - pui- kiai. Daugiau nei pusė tiriamųjų nuotolinių ergoterapijos užsièmimų patirtị ivertino gerai, o likusi dalis - puikiai. Nei vienas tiriamasis šios patirties neįvertino blogai. Tai rodo, kad nuotoliniai užsièmimai gali būti puikus paslaugos teikimas, kai užsièmimas realiai susitinkant negalimas. Visi tiriamieji atsaké, kad dar kartą naudotųsi nuotoliniais užsièmimais bei juos rekomenduotų kitam asmeniui (1 lentelè).

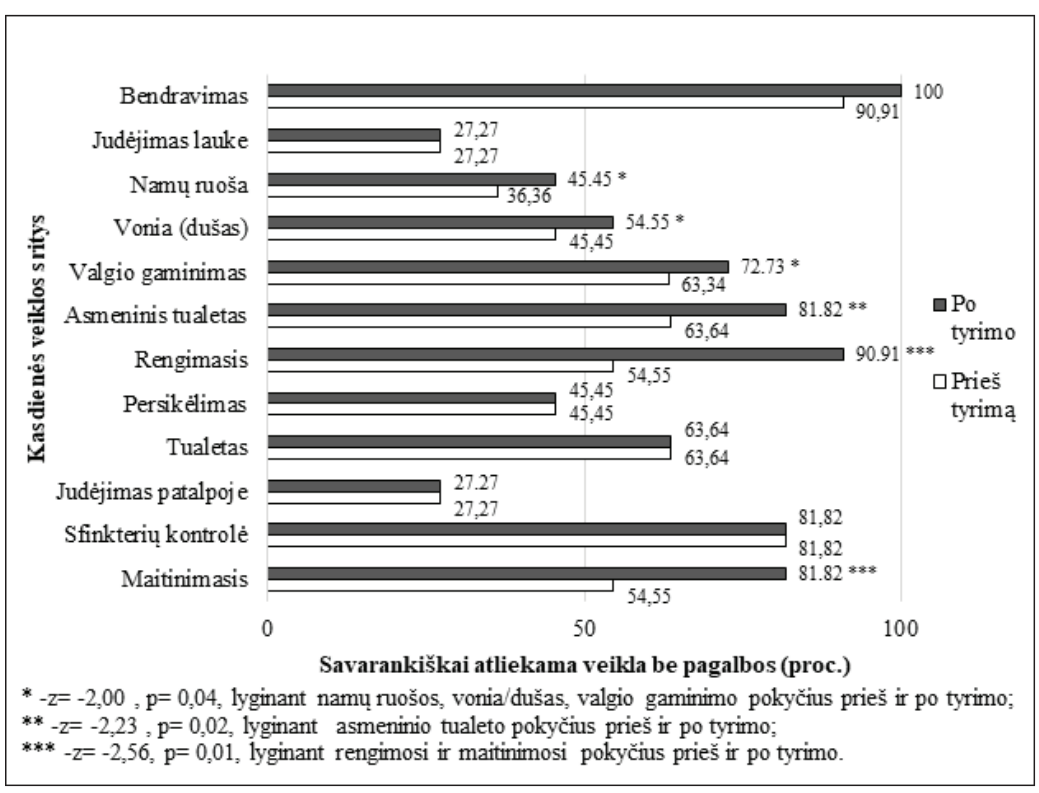

4 pav. Tiriamųjų pasiskirstymas pagal kasdienès veiklos sritis prieš ir po nuotolinès ergoterapijos

1 lentelè. Tiriamųjų nuotolinių ergoterapijos užsièmimų įvertinimas.

\begin{tabular}{|l|l|l|l|l|}
\hline \multirow{2}{*}{ Klausimai } & \multicolumn{5}{|l}{ Ivertinimo pasiskirstymas (proc.) } \\
\cline { 2 - 6 } & prastai- 1 & neblogai- 2 & gerai- 3 & puikiai- 4 \\
\hline Garso kokybė & - & 18,18 & 27,27 & 54,55 \\
\hline Vaizdo kokybė & - & - & 54,55 & 45,45 \\
\hline $\begin{array}{l}\text { Asmeninis patogumas taikant nuoto- } \\
\text { linị būdą }\end{array}$ & - & - & 9,09 & 90,91 \\
\hline Patekimas į nuotolinị užsièmimą & - & - & 18,18 & 81,82 \\
\hline Laiko trukmė susitikimams & - & 18,18 & 27,27 & 54,55 \\
\hline Paaiškinimas apie gydymą & - & - & 27,27 & 72,73 \\
\hline $\begin{array}{l}\text { Ergoterapeuto kruopštumas, atsargu- } \\
\text { mas, sumanumas }\end{array}$ & - & - & - & 100 \\
\hline $\begin{array}{l}\text { Ergoterapeuto mandagumas, pagarba, } \\
\text { draugiškumas }\end{array}$ & - & - & - & 100 \\
\hline Vykusi laiko trukmė & - & - & 54,55 & 45,45 \\
\hline Atsakymas ị klausimus apie ịrangą & - & - & 18,18 & 81,82 \\
\hline Paisoma privatumo & - & - & 18,18 & 81,82 \\
\hline $\begin{array}{l}\text { Bendra patirtis, taikant nuotolinị } \\
\text { būdą }\end{array}$ & - & - & 54,55 & 45,45 \\
\hline
\end{tabular}




\section{Išvados}

1. Po taikytų nuotolinių ergoterapijos užsièmimų sergančiųjų išsėtine skleroze gyvenimo kokybė nepasikeitè, tačiau pagerejo emocinè savijauta ir fizinè būklè.

2. Asmenims, sergantiems išsètine skleroze, taikyti nuotoliniai ergoterapijos užsiėmimai pagerino bendrą savarankiškumą bei atskiras jo veiklas, tokias kaip namų ruoša, vonia (dušas), valgio gaminimas, asmeninis tualetas, rengimasis ir maitinimasis.

3. Tiriamųų patirtis, taikant nuotolinius užsièmimus, îvertinta teigiamai. Tiriamiesiems nuotoliniai užsièmimai buvo puiki alternatyva gauti ergoterapijos paslaugas karantino metu.

\section{Literatūra}

1. Amatya B, Khan F, Galea M. Rehabilitation for people with multiple sclerosis: an overview of Cochrane Reviews. Cochrane Database Syst Reviews 2019;1(1):2-16. https://doi.org/10.1002/14651858.CD012732.pub2

2. Botsis T, Demiris G, Pedersen S, Hartvigsen G. Home telecare technologies for the elderly. J Telemed Telecare 2008;14(7):333-7. https://doi.org/10.1258/jtt.2008.007002

3. Guo HJ, Sapra A. Activities of Daily Living. StatPearls 2020. https://www.ncbi.nlm.nih.gov/books/NBK553126

4. Yeroushalmi S, Maloni H, Costello K, Wallin MT. Telemedicine and multiple sclerosis: A comprehensive literature review. J Telemed Telecare 2019;26(7-8):400-413. https://doi.org/10.1177/1357633X19840097

5. Yu CH, Mathiowetz V. Systematic review of occupational therapy-related interventions for people with multiple sclerosis: Part 1. Activity and participation. American Journal of Occupational Therapy 2014;68:27-32. https://doi.org/10.5014/ajot.2014.008672

6. Keesara S, Jonas A, Schulman K. Covid-19 and Health Care's Digital Revolution. The new England Journal Medicine 2020;382(23).

https://doi.org/10.1056/NEJMp2005835

7. Larocca NG. Impact of walking impairment in multiple sclerosis: perspectives of patients and care partners. Patient 2011;4(3):189-201.

https://doi.org/10.2165/11591150-000000000-00000

8. Maitra K, Hall C, Kalish T, Anderson M, Dugan E, Rehak J, Zeitlin D. Five-Year Retrospective Study of Inpatient Occupational Therapy Outcomes for Patients With Multiple Sclerosis. Am J Occup Ther 2010; 64(5):689-694.

https://doi.org/10.5014/ajot.2010.090204

9. Morgan DG, Kosteniuk J, Stewart N, O'Connell M.E, Karunanayake C, Beever R. The telehealth satisfaction scale: reliability, validity, and satisfaction with telehealth in a rural memory clinic population. Telemed J E Health 2014;20(11):997-1003. https://doi.org/10.1089/tmj.2014.0002

10. Multiple Sclerosis International Federation, 2021. https://www.msif.org/about-ms/what-is-ms/

11. The Telehealth Satisfaction Scale (TeSS). HTF 402 National First Nations Telehealth Research Project. 2021. https:// digital.ahrq.gov/sites/default/files/docs/survey/telehealthsatisfactionquestionnaire_comp.pdf

12. Vickrey BG. Multiple Sclerosis Quality of Life (MSQOL)-54 Instrument. 1995. https://www.nationalmssociety.org/ NationalMSSociety/media/MSNationalFiles/Brochures/ MSQOL54_995.pdf https://doi.org/10.1037/t53653-000

13. World Health Organization. 2021. https://www.who.int/health-topics/rehabilitation\#tab=tab_1

THE IMPACT OF REMOTE OCCUPATIONAL THERAPY OCCUPATIONS ON THE QUALITY OF LIFE AND SELF-SUPPORT OF PEOPLE WITH MULTIPLE SCLEROSIS

\section{E. Liubinaitè, E. Lamsodienè}

Keywords: multiple sclerosis (MS), remote occupational therapy, quality of life, daily activities (ADL), independence.

Summary

More than 2.5 million people worldwide have multiple sclerosis. With the onset of the COVID-19 pandemic, countries around the world began to restrict contact meetings, making it more difficult for people to access treatment. The aim of the study was to evaluate the impact of remote occupational therapy sessions on the quality of life and independence of patients with multiple sclerosis. Assessing the quality of life of patients with multiple sclerosis, it was found that the quality of life of the group, among the subjects, is average. The assessment of patients' daily activities revealed that they needed assistance in such activities as: outdoor and indoor activities, moving bath/shower, preparation, housekeeping, meals. At the very least, according to the daily performance evaluation questionnaire, subjects need help with activities such as: cooking, sphincter control, personal toilet, and communication. After the applied remote occupational therapy sessions, the quality of life of patients with multiple sclerosis did not change, but the individual areas: emotional well-being and physical condition. For people with multiple sclerosis, remote occupational therapy sessions have improved overall independence and individual activities such as housekeeping, bath/ shower, cooking, personal toileting, preparation, and eating. The experience of the subjects using distance learning was evaluated positively.

Correspondence to: evelina.lamsodiene@gmail.com

Gauta 2021-09-29 